\title{
DE LA GUERRA A LAS SOMBRAS: SOBRE LOS PASOS DE PEREGRINACION DE RENÉ MARQUÉS
}

\author{
POR \\ JORGE LUIS CASTILLO \\ Harvard University
}

Peregrinación figura en la historia literaria de hispanoamérica como la obra primogénita de René Marqués y constituye asimismo su único poemario. Estos datos bastarían para resal tar la importancia de este libro dentro de la obra del gran dramaturgo y narrador puertorriqueño; pero, tal vez debido a la brevedad (22 poemas), a las modestas circunstancias en que se publicó el poemario y a su mínima divulgación (nunca ha sido reeditado), la atención dispensada a Peregrinación por parte de la crítica ha sido escasa.

La principal excepción a lo anteriormente dicho reside, a saber, en un acertado estudio de Arcadio Díaz Quiñones, quien ha encontrado en este fruto de juventud (escrito en 1944, cuando el autor contaba 25 años) una valiosa guía expositoria de los que serían motivos centrales y recurrentes en las obras futuras de René Marqués. ${ }^{1}$ En el trabajo de este crítico, Peregrinación ha sido utilizado como una suerte de muestrario ideológico para extraer de él muchas de las ideas que Marqués habría de desarrollar en el resto de su producción; artículos como el de Diaz Quiñones, sin embargo, revelan aún más la falta de un estudio que examine el poemario a la luz de sus propios méritos, por escasos que éstos fueren, y no es otra la tarea que proponen estas páginas.

Vale la pena señalar también que otro grupo de críticos sí llegó a ocuparse de la obra, en unas pocas reseñas, a raíz de su publicación; pero lo hizo fundamentalmente para adjudicarle juicios adversos, tras reparar en la manifiesta rudeza de su adjetivación y en lo poco afortunado de algunas de sus imágenes, si bien algunos de ellos le concedieron al poemario un profundo y auténtico valor ideológico.

El mismo René Marqués, por su parte, no tenía muy buena opinión de este libro, al cual llamó "un pecado de adolescencia", puesto que, según cuentan, destruía toda copia que cayese en sus manos, ${ }^{3}$ en un gesto de autocensura

\footnotetext{
${ }^{1}$ Arcadio Díaz Quiñones, "Los desastres de la guerra: para leer a René Marqués". El almuerzo en la hierba (Río Piedras: Huracán, 1982).

${ }^{2}$ Wilfredo Braschi, "René Marqués". El Mundo 23. San Juan, 23 de octubre de 1956.

3 Efraín Barradas, "El machismo existencialista de René Marqués". Sin Nombre 3 (octubre-diciembre, 1977) 62.
} 
hipercrítica que trae a la memoria similares acciones por parte de un Borges o de un Juan Ramón Jiménez.

El título del poemario remite de inmediato a la venerada tradición de la peregrinación religiosa, costumbre compartida, desde tiempos muy remotos, por cultos antiguos y modernos y que todavía consiste en el viaje de una o varias personas a un determinado lugar sagrado para adorar a una divinidad. Dentro de una tradición religiosa más cercana a Marqués, existe en el dogma judeocristiano, específicamente en el católico, el concepto de la peregrinatio que ve a la existencia humana como un continuo deambular entre la cuna y la sepultura, en búsqueda de un sentido que, en último caso, es Dios. El poemario de René Marqués se fundamenta, en efecto, en el motivo de la peregrinación como búsqueda de sentido; pero, excepto por alguna que otra alusión a Cristo, relega a un segundo plano la experiencia religiosa para, en primer lugar, cantarle a la patria opresa y concentrarse luego en los problemas esenciales de la condición humana, llamado a esto sin duda por las enseñanzas del existencialismo francés. ${ }^{4}$

Otro tópico presente en el poemario es el ancestral motivo del viaje. Peregrinación traza el itinerario de un viaje alegórico cuyo propósito final es hallar un sentido para la atormentada existencia humana. Sin llegar, por esta vía alegórica, a coincidir con las visiones oníricas de aquellos viajes espirituales o metafísicos en donde el alma viaja fuera del cuerpo, prevalece en Peregrinación la idea del viaje (real o imaginario) como un medio de conocimiento, motivo presente en la literatura moderna desde el Renacimiento, debido, por un lado, a los desplazamientos geográficos en el nuevo continente $\mathrm{y}$, por otro, al entusiasmo que despierta en la época todo lo relativo a la experiencia humana.

Por otra parte, la filiación de René Marqués con la herencia romántica, cuyas huellas y sensibilidad son evidentes en Peregrinación, le permiten concebir al viaje, no sólo como un medio de conocimiento, sino como una manera de escapar de una sociedad hostil o de un destino adverso. Marqués concibe como protagonista del viaje a un poeta-peregrino, figura de abolengo romántico (héroe, poeta) y bíblico (peregrino), arquetipos ambos del hombre "desterrado y extranjero sobre la tierra". ${ }^{5}$ En la concepción del poeta como un paria social, forzado a peregrinar en busca de una patria y de una justificación para su existencia como individuo en el mundo, es cierta la deuda (directa o indirecta) de Marqués con las peregrinaciones románticas decimonónicas del tipo Childe Harold o Wilheim Meister, en las cuales la búsqueda del kyo» durante los viajes

\footnotetext{
- Las huellas del existencialismo, especialmente el de la vertiente cultivada por Sartre y por Camus, son notables a lo largo de toda la producción literaria de René Marqués, especialmente en obras de teatro como La casa sin reloj (1960) y El apartamiento (1966). "Véase Antonio Vilanova, "El peregrino andante en el Persiles de Cervantes", Boletín de la Real Academia de las Buenas Letras de Barcelona, XXII (1949) 97-159. Puede complementarse la cita de Vilanova con la lectura de los versículos 11: 13-16 de la Epístola de los Hebreos, a los cuales, sin duda, el eminente crítico hace alusión.
} 
del héroe es tan o más importante que la búsqueda de un conocimiento del mundo sensible o inteligible. La literatura hispanoamericana, por su parte, supo recoger muy bien la herencia de estos peregrinajes románticos en obras como Los cantos del peregrino del argentino José Mármol y, en especial, en La peregrinación de Bayoán, única novela del puertorriqueño Hostos, cuyo empleo de la narrativa alegórica, amén de sus descripciones de la travesía y vicisitudes del protagonista, no pudo escapársele a Marqués.

El valor principal de Peregrinación parece residir en la sinceridad que infunde a los temas trabajados, los cuales se sitúan, como se dijo, dentro del tradicional motivo del viaje y en la figura no menos arquetípica del poeta como peregrino. En su peregrinar, el poeta viaja a cinco mundos, los cuales constituyen, además de un poema prólogo, sendas partes en el orden interior del poemario y que son: la guerra (3 poemas), la tierra ( 7 poemas), la luna (3 poemas), el amor (2 poemas) y las sombras ( 6 poemas).

Una lectura rápida del poemario, por su parte, revela que la lengua poética de René Marqués propende a la sencillez y a la expresión directa, inmediata y descarnada, aunque cultiva también, en ocasiones, metáforas, símbolos y léxico preciosista, cuyo abolengo modernista es evidente. La adjetivación, escasa por lo general, propende a lo austero, a tenor quizás con la materia poética descrita, aunque el uso de adjetivos tiende a aumentar en las últimas tres partes del poema, y en las peregrinaciones a la luna y al amor hay un intento por crear versos más sensuales y exquisitos mediante la selección de epítetos. El ritmo poético, a su vez, no se manifiesta en constantes rítmicas o en metros discernibles, con excepción del ocasional octosílabo arromanzado y de unos pocos endecasilabos.

Algunas figuras que dejaron alguna huella en la impronta poética de René Marqués fueron su coterráneo Luis Palés Matos y el cubano José Martí (en especial con su Ismaelillo) junto al Pablo Neruda de los Veinte poemas ... y al Federico García Lorca del Romancero gitano y del Poema del Cante Jondo. Aparte del trasfondo religioso explícito en el poemario, hay asimismo en éste, como veremos, una fuerte carga ideológica que proviene del existencialismo y que se entrevera con las preocupaciones políticas del propio Marqués.

En el poema que sirve de prólogo, el poeta-peregrino expone la imagen que tiene de sí mismo y de su ideario poético. Se presenta como "nervio en perpetuo insomnio, verdugo de la risa, receptáculo trágico de búhos y de cisnes, golpeador de rosales y de palomas" (5). ${ }^{6}$ Aunque en otros momentos se acoja a ella, e] peregrino rechaza aquí la poesía formalista, rebuscada, musical, de corte modernista (la "poesía de los cisnes"); en cambio pretende ser el poeta que "golpea los versos ... no es el poeta de las academias, es la trágica lucha de una voz despierta" (6), la cual ha de llevar su mensaje, su clamor de protesta, tanto

- Cito por la única edición de Peregrinación (Arecibo, San Juan: Imprenta Venezuela, 1944), dando el número de página entre paréntesis. Debo el acceso a esta edición, hoy rara, a la amabilidad de J. J. Beauchamp. 
contra la pérdida de la tierra a manos del enemigo, como contra la guerra que desangra en esos momentos al mundo.

Esta última preocupación constituye la materia de la peregrinación inicial. Al incursionar el mundo de la guerra, el poeta se adentra en una dimensión trágica y dolorosa, y habla de ella con honda amargura y negro pesimismo. La muerte, omnipresente y ya presagiada, adviene en "Campamento", descrito este lugar como un "cementerio de almas muertas" en el cual tremola una bandera de siete chorros de sangre (la bandera estadounidense) y, asimismo, se deja sentir en "Oración roja en la muerte del labriego", donde el hombre campesino se halla "prisionero en la selva" militar dentro de la cual le toca vivir "la noche del silencio".

Esta peregrinación a la guerra, inspirada sin lugar a dudas por la Segunda Guerra Mundial que se peleaba entonces y en donde lucharon y murieron muchos soldados puertorriqueños, plantea un tema clave en la obra de René Marqués: la dependencia política y económica de Puerto Rico con respecto a los Estados Unidos vista como un desastre para los puertorriqueños. ${ }^{7}$ Esta situación, para Marqués una tragedia, arranca de la pluma del poeta un grupo de imágenes y motivos que ejemplificarán todo el mundo anímico de un hombre herido por la "metralla de mentiras". Abundan entre ellos los colores trágicos, negro, rojo y gris: para el poeta el negro significa la maldad, el odio, el misterio; el rojo, la sangre, y el gris, los uniformes de los soldados. Así hallamos a este último en "momias grises" (los soldados), en "peste gris de disciplina" y en "sombras grises atrofiadas de futuro" ("Campamento", 9-10); los tonos negros aparecen, por su parte, en la "negrura de la noche", la "mancha negra", y en el "infierno negro"; mientras que el rojo siempre se derrama con la sangre del labriego, símbolo del puertorriqueño llevado a morir en una guerra juzgada por el poeta como absurda y estéril. Otras imágenes correspondientes al mundo de la guerra son las relativas al infierno, la tragedia, la selva y el silencio. Estas imágenes, de un pesimismo tremendista, como se verá, no aparecerán únicamente en esta sección del poemario, sino que recurrirán en tanto el poeta aluda a un mundo trágico o destructivo.

La segunda peregrinación nos lleva a la tierra, tema importantísimo en la producción de René Marqués, quien fundamenta lo más granado de su producción teatral - "La carreta" (1951), "Los soles truncos" (1958) y "Un niño azul para esa sombra" (1958) - en el motivo de la pérdida de la tierra y en la añoranza de recuperar la misma. No debe olvidarse que, ideológicamente, René Marqués está vinculado a la pasada tradición agrícola de la hacienda cafetalera, decimonónica y señoril, contemplada como paradigma de pureza y desplazada sucesivamente como sistema económico en este siglo por el cultivo de la caña de los años 30 y la industrialización, que se inició a comienzos de los años 50, para darle el golpe de gracia al mundo agrícola en pro de lo urbano. Esta "afrenta

${ }^{7}$ Díaz Quiñones 147. 
infame" hará salir del poeta, "el hombre de tierra", imágenes similares que sirven para unir dos mundos trágicos: la guerra impuesta por el amo (los Estados Unidos) y la tierra arrebatada por éste, transformado en "un chacal de tierras negras" para apoderarse de la tierra-madre-hembra-amante, quien antes, también personificada y sexuada, ofrecía al hijo-amante "guedejas de cafeto" y la turgencia de sus montes. ${ }^{8}$ El hijo-amante se torna entonces negro de odio y jura vengar el ultraje. La sangre del chacal-amo constituirá un ritual purificador al derramarse sobre la tierra en "Canción cínica para no ser cantada", poema cuyo título revierte el de la famosa "Canción festiva para ser llorada" de Palés Matos:

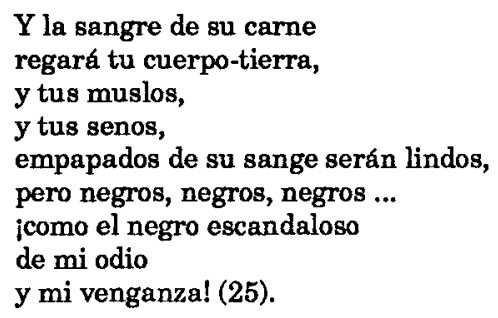

Este llamado a la lucha violenta contra el poder opresor tiene lugar mediante reconocibles imágenes que remiten a lo negro, lo trágico, y terminan en silencio. El silencio es uno de los motivos más usados en el poemario, pero sus sentidos son múltiples. Suele relacionarse al mundo tétrico de la violencia o al de la tierra infecunda y domeñada; expresa también impotencia, frustración, desesperanza, esterilidad, aunque así mismo intuya experiencias o sentimientos, para el poeta, inefables. En "El pozo", que también recuerda, por su título más que por su tono, a otro poema de Palés Matos, René Marqués personifica precisamente la esterilidad, la impotencia. Habla entonces de un "pozo de agua muerta" (20), eternamente muerta, ya sin esperanzas.

El pesimismo del poeta continúa manifestándose en "El hombre de la tierra", presentado como víctima del "silencio estéril" (29) y quien no es otra cosa que un símbolo del puertorriqueño dócil, "bestia pobre y agonizante", presa fácil de la opresión extranjera al ser torturado por un buitre que le devora las entrañas como a Prometeo; ante este hombre, y pese a verlo sumido en el oprobio, el peregrino concibe alguna esperanza al afirmar que "echaría a las aves lenguas de palomas", es decir, cantaría en un lenguaje florido, grácil y lleno de júbilo, si la bestia algún día se tornara en hombre libre.

\footnotetext{
${ }^{8}$ Es preciso recordar aquí las oposiciones temáticas monte-llano, café-caña, tan explotadas por la obra literaria de la llamada generación del 30 . Véanse al respecto las novelas $L a$ llamarada de Enrique Laguerre (1935) y La vispera del hombre, del propio René Marqués (1959), que ilustran este punto, más el estudio, Imagen del puertorriqueño en la novela de J. J. Beauchamp (Río Piedras: UPRED), entre otros.
} 
El mismo amor a la tierra se manifiesta en "Vida, pasión y muerte de mi río isleño", donde este cuerpo de agua se transfigura en el cuerpo de Cristo crucificado, principal símbolo religioso de todo el poemario. El río de aguas puras, proveniente de la montaña, de los cafetales, se contamina al llegar a la llanura, juntoal "monstruo empenachado de gasas negras" (la central azucarera); los residuos de la caña manchan sus aguas, volviéndolas dulzonas, negras. Haciendo gala de una especie de humildad cristiana, el río se refugia sumiso junto al pueblo. Es un río mártir, donde los enemigos arrojan heces que vuelven lento su cauce, por los desperdicios, "crucificado en sal y en verde".

"Tierra triste" es también una elegía desesperanzada a una tierra que se ha vuelto estéril, para ella el poeta tiene sólo "palabras duras, frías, yertas, sin bellezas ni poesía" (39). La tierra es también el pueblo, un "pueblo cisne", que no ha nacido para hijastro de las águilas (símbolo arquetípico del opresor, a quien Marqués siempre identifica con los Estados Unidos). Esta tierra, sin embargo, ha optado por vivir junto con sus habitantes en un trágico silencio, sin rebelarse, porque:

La tristeza te ha hecho humilde, la impotencia te ha hecho esclava, la colonia te ha extirpado los ovarios ... (38).

En “Un alto en la faena”, las imágenes trágicas, el pesimismo negro, se aclaran un poco porque vislumbra el poeta la posibilidad de una purificación, ${ }^{10}$ la cual logra concebir gracias al vínculo final del hombre con la tierra que un día lo nutrió y ahora cubre sus despojos. El blanco es en este poema el color de la purificación que libera al hombre del pecado de la docilidad: la estrella blanca, el cielo azul, los surcos rojos y unas franjas de palomas blancas forman la bandera de la patria puertorriqueña, la cual se lleva el poeta a su tumba. Aunque la purificación no habrá de alcanzarse si no en la muerte, este poema carece del tono trágico de los anteriores; en su lugar surge un sentimiento de nostalgia, algo más leve que las imágenes intensas de destrucción, violencia y negrura. El predominio del color blanco preludia, en efecto, una dimensión distinta a la que el poeta-peregrino no tardará en adentrarse.

Concluida su peregrinación por los mundos de la guerra y la tierra, el poeta asciende a esferas un tanto más benévolas, puesto que las peregrinaciones a la luna y al amor marcan un contraste inesperado dentro de la visión lúgubre y

- La imagen de la pasión es común en la obra de René Marqués. Véase la muerte de Michelín en Un niño azul para esa sombra y la escena de la prisión en su novela La mirada (Río Piedras: Editorial Antillana, 1976) 63-65.

${ }^{10}$ Otro tema favorito de Marqués, cuya expresión cumbre está en Los soles truncos, donde el fuego es el elemento purificador. Muchas veces, diría Marqués, la tierra, el centro de todo lo humano, necesita purificarse de los "bárbaros" que la poseen. 
pesimista que el poeta tiene de la realidad. El sentimiento trágico, las metáforas que ilustran una realidad doliente, dan paso a imágenes donde predomina el color blanco, es decir la pureza y la alegría, como en "Fuga en tono blanco hacia la luna", en la cual el poeta quiere que le laven "la negrura de sus manchas" para que éstas no enturbien sus sueños angustiados. Es decir, el poeta quiere soñar, huir de una realidad irrefragable, y se refugia en la luna (mundo opuesto a la tierra) y en el amor (sentimiento opuesto al odio): "En la tierra se ha quedado mi tragedia..../ihoy regreso a mi castillo de poeta!" (46). El poeta-peregrino vive la fiesta de la blancura, escapa de la tierra, de la sangre y del dolor, en versos de resonancias lorquianas y martianas:
Al galope, lucerito, ya la luna nos saluda agitando su pañuelo (con la plata de mi espuela rompe nardos en la carne del lucero)
iA la fiesta, a la fiesta de mis sueños! (fiesta nácar, fiesta nívea) Ya la fiesta seca el llanto de mi niña, ¡llanto blanco que acaricia como armiño! (47).

Las imágenes que representan lo blanco dominan toda la peregrinación a la luna (el astro blanco por excelencia). El mismo patrón de metáforas blancas continúa en "Embrujo de luna", pero ya empieza a ceder en "Crepúsculo", donde el poeta es herido por el amor, que ya se anunciaba en los dos poemas anteriores. "Crepúsculo" es un poema de tránsito entre la peregrinación a la luna y la peregrinación al amor, del mismo modo que "Un alto en la faena" medió, con sus atisbos de blancura, entre la pesadilla terrestre y el ensueño lunar.

La maternidad es el motivo central de la peregrinación al amor. Contrasta con la anterior al abandonar el tono lúdico y las metáforas frivolas, de corte modernista, por una expresión de intimidad y recogimiento más genuinos. El poeta es capaz de amar, de producir un fruto, de vencer, por fin, la esterilidad que lo atormentaba en los mundos anteriores. El poeta le canta, sobre todas las cosas, a la madre, quien dejó de ser silencio al concebir un hijo. Así el paisaje también reverdece y recobra su esplendor, ya convertido en locus amoenus, en "El milagro de mi valle":

\footnotetext{
Hoy en mi valle renacen las cascadas, florecen los naranjos y los lotos hieráticos
} 
se abren para ti

en un estanque claro ... (37).

Este mundo ideal desaparece para siempre cubierto en la penumbra cuando el poeta emprende su última peregrinación al mundo de las sombras. Ya en "Confesión", poema de transición, el poeta confiesa que no puede soñar más ni escribir los versos que nunca en verdad ha sentido: sonetos floridos, expresión delicada y sutil, versos musicales y rítmicos, imágenes y adjetivación de corte modernista o lorquiano. Vuelve al verso duro, a cantar el dolor de la tierra, de un pueblo en cadenas; sus versos vuelven a ser "el dolor de lo vivo" (64).

Por fin, las sombras lo invaden completamente en "El sueño de las sombras" donde canta la muerte de un ser amado, de una mujer amada:

Tendida está sobre mis sueños duros:

su pelo es un abismo de negruras,

su boca se ennegrece mutilada,

ihay dos infiernos de noche enloquecida

en el mentido fulgor de su mirada! (65).

La noche, la negrura, el infierno y el silencio se ciernen sobre el alma del poeta que se siente tan muerto como la amada: " $¡$ Yo soy el muerto en esta extraña vida!". La cercanía de la muerte produce en el poeta una nueva toma de conciencia: "Las sierpes negras se enroscan a mi cuerpo. Despierta la conciencia". Siente también el "dolor de luces blancas". El blanco colorido es ya apenas un vago fantasma que desaparecerá para siempre ante la noche y el dolor de las "sombrías realidades". El ensueño del poeta-peregrino finalmente muere. Está en las sombras, de nuevo solo, dentro de una soledad llena de infecundo silencio ("Sonata de la soledad"); inmerso en un mundo-prisión donde la soledad y el silencio son una misma cosa:

Soledad de penumbras ...
soledad ...
soledad y silencio
y frío de las sombras (70).

La soledad, la oscuridad y el silencio acompañan al peregrino en éste, su postrero viaje.

"Naufragio" recrea, con destellos nerudianos, la visión de la mujer amada en su féretro "entre rocas de plumas ...", sus ojos son "pozos de noche" su alma ha naufragado en una nave de cuatro mástiles (el ataúd flanqueado por cuatro cirios).

Después de haberse enfrentado a la realidad externa, en la peregrinación a las sombras, el poeta se enfrenta a su propia interioridad, "encrespada como un mar" ("Ese mar ..."). Ante los ojos del poeta, el mar, tempestuosoy destructor, 
aparece como una presencia negativa de signo opuesto a la tierra plácida y fértil, a la cual circunda y aprisiona.

El viaje del peregrino culmina en "Péndulo eterno" que muestra el ser del poeta por entero, oscilando entre la nada y el infinito. Este poema, de rasgos existencialistas muy marcados, enfrenta al poeta con el absurdo de la vida:

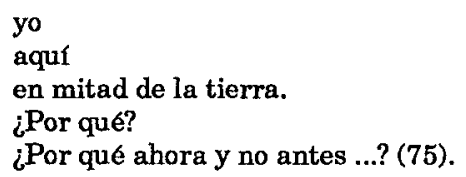

La voz del poeta es un péndulo eterno que golpea dos puntos: la nada (el origen) y el infinito (el porvenir) en busca de una razón de ser que no encuentra. Nadie ni nada contesta su pregunta. El poeta confiesa que:

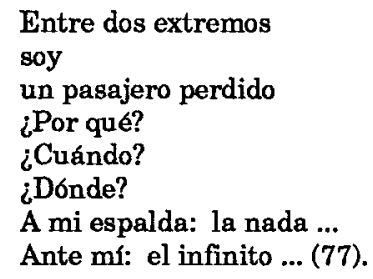

La soledad personal ha desembocado así en la soledad existencial. El poeta siente la nada dentro de sí y se detiene a contemplar su vida como un instante entre dos abismos: la nada y el infinito. Experimenta una sensación de vacío interior: su vida no tiene sentido en el presente y desespera de hallarlo en el porvenir. El viaje, como medio de conocimiento, ha redundado en un gran fracaso. El poeta concluye entonces su travesía "inmerso en el silencio" de su propia intimidad como entidad en busca de sentido, el cual Marqués situó en la posesión de una tierra que le fue arrebatada, y en el ser puertorriqueño, identidad por la cual luchó con todas sus fuerzas hasta la muerte, el "eterno silencio".

Por escapar del amo que usurpa la tierra y obliga a los hijos de ésta a pelear por él, se refugia el poeta en los mundos de la luna y del amor. Pero la dolorosa realidad golpea implacable a las puertas de su ensueño, y al poeta no le queda otro recurso que descender al mundo de las sombras, donde se aleja, tanto de la guerra y de la tierra como de la luna y del amor. Ese mundo de las sombras concluye por ser entonces una especie de síntesis que surge de dos pares de opuestos; es decir: guerra/amor y tierra/luna (exterioridad/interioridad). Las imágenes de negrura, violencia y odio se oponen a lasimágenes donde predominan lo blanco, lo suave y lo musical. La insufrible realidad externa se opone al 
atormentado mundo interior del poeta. Las sombras son sinónimo de la desesperanza, de la desilusión que lleva el poeta dentro de su ser.

El viaje imaginario que emprendiera el peregrino en búsqueda de un sentido para sí mismo y la vida culmina con el desengaño y el fracaso de esta empresa. Dios no está al final del viaje, ni hay promesas de un futuro que vengan a redimir las cuitas del errante peregrino despojado de la patria. Tampoco el peregrino encuentra respuestas que contesten sus preguntas o justifiquen su suerte de "pasajero perdido" en el caos de la existencia. Al no hallar consuelo alguno para sus penas innúmeras y al no poder resignarse a una vida de cautivo, de súbito callado y dócil, el poeta se aboca pues al silencio, a las sombras y a la muerte, como al último refugio de un hombre sin esperanzas.

Arcadio Díaz Quiñones señala con justicia que "Marqués esboza en Peregrinación un código que permanecería casi idéntico hasta el final". Y describe el libro como un sermón religioso-patriótico, una parábola y una alegoría de la Caída, el Pecado, la Vida, Pasión y Muerte. ${ }^{11}$ Es muy cierto que las posturasideológicas de Marqués no evolucionan, sólo se reiteran y amplifican. Siendo así, parece asombrosa la actitud de claro rechazo de Marqués hacia su poemario. ¿Por qué repudiaría Marqués algo que luego reitera y amplifica?

En primer lugar, seguramente Marqués tenía conciencia de la contradicción en que incurría su libro al estar contaminado en parte por un lenguaje de corte modernista cuyo uso es criticado en otros pasajes del mismo libro. Marqués se preció siempre de cultivar "palabras duras"; por eso, con toda probabilidad, al rechazar su poemario, no repudiaba sino esa vacilante incursión suya dentro de un estilo cuyo empleo del lenguaje tiende a real zar los valores fónicos, rítmicos y connotativos del significante lingüístico, relegando a un plano ancilar la función referencial del significado; es decir, Marqués critica su propio devaneo escapista, su juego y complacencia con las "metáforas blancas" en las peregrinaciones a la luna y al amor, despojadas ambas de las "palabras duras" que él decía preferir.

En segundolugar, desde una-no menos importante-perspectiva temática, Marqués repudiaría la falsa conciencia implícita en la creación de un locus

\footnotetext{
11 En su detenido análisis, Díaz Quiñones, 152, coloca a un mismo nivel de importancia el discurso religioso y el patrítico o político. Pensamos, por el contrario, que el primero está supeditado definitivamente al segundo, afirmación perfectamente sostenible si se repara en el siguiente ejemplo. En "Vida, pasión y muerte de mi río isleño", la figura más bien, el símbolo- de Cristo es utilizada para describir los males sufridos por el río isleño contaminado de desperdicios. El río está crucificado como Cristo: la imagen de Cristo expresa la vejación sufrida por el río, y no al revés. En otras palabras, a Marqués le preocupan más las aflicciones de la economía y la ecología de Puerto Rico que la pasión y muerte de Cristo, aunque utiliza las segundas para describir los males del primero, cuyo emblema es el rí; todo lo anterior no quiere decir en modo alguno que el discurso religioso no sea importante en el poemario, pero sí que funcionalmente, está subordinado al discurso político o patribtico.
} 
amoenus, es decir su alejamiento momentáneo del motivo de la tierra puertorriqueña arrebatada por el enemigo, de aquella visión trágica de la patria perdida, exhibida en la parte inicial y final de su poemario y luego en el resto de su producción, para culminar quizás en la purificación wagneriana de Los soles truncos. Por eso, después de esta aventura poética, el resto de su producción se consagra, en su mayor parte, a explotar esa imagen trágica de la realidad puertorriqueña y a criticar de manera militante y combativa los males que la azotan. No supo perdonarse, sin embargo, ese "pecado de adolescencia", y, mediante ungesto extremista de rígida autocensura, quiso negarle a la posteridad la curiosa singularidad de un fruto temprano de su atormentado espíritu. 
